\title{
Clusterin Promotes the Aggregation and Adhesion of Renal Porcine Epithelial Cells
}

\author{
John R. Silkensen, * Keith M. Skubitz, * Amy P. N. Skubitz, ${ }^{\ddagger}$ David H. Chmielewski, * J. Carlos Manivel, \\ Jeffrey A. Dvergsten, * and Mark E. Rosenberg* \\ ${ }^{*}$ Department of Medicine and ${ }^{\ddagger}$ Department of Laboratory Medicine and Pathology, and ${ }^{\S}$ Biomedical Engineering Center, \\ University of Minnesota, Minneapolis, Minnesota 55455
}

\begin{abstract}
The function of clusterin, a heterodimeric glycoprotein markedly induced in renal and other organ injuries, is unclear. Since renal injury is accompanied by alterations in cell attachment, it is possible that clusterin functions to promote cell-cell and cell-substratum interactions. In this study, a single cell suspension of renal epithelial (LLC-PK1) cells was treated with purified human clusterin, resulting in timeand dose-dependent cell aggregation. Electron microscopy of the cell aggregates demonstrated cell junction and lumen formation. To determine the effect of clusterin on cell adhesion, tissue culture plates were coated with clusterin, fibronectin, PBS, or albumin. Clusterin and fibronectin promoted cell adhesion to the same extent. The adhesion to clusterin was dose dependent and specific, as a monoclonal antibody against clusterin inhibited cell adhesion to clusterin but not fibronectin. Perturbations of the cytoskeleton may underlie the alterations in cell attachment which occur in renal injury. Induction of clusterin mRNA was seen after disruption of both microtubules and microfilaments and after inhibition of cell-substratum interactions. In conclusion, clusterin is a potent renal epithelial cell aggregation and adhesion molecule. We speculate that clusterin functions to promote cell-cell and cell-substratum interactions which are perturbed in the setting of renal injury, thereby preserving the integrity of the renal epithelial barrier. $(J$. Clin. Invest. 1995. 96:2646-2653.) Key words: kidney tubules • acute kidney failure • glycoprotein - cell communication • lipoproteins
\end{abstract}

\section{Introduction}

Clusterin, a glycoprotein first isolated from ram rete testes fluid, is named for its ability to elicit the clustering of a number of cell types $(1,2)$. Species and tissue homologues of clusterin have been isolated and/or cloned by groups working in widely divergent areas (3-7). This has resulted in multiple names for clusterin, including complement cytolysis inhibitor (CLI),

Address correspondence to John R. Silkensen, M.D., University of Minnesota, Department of Medicine, Box 736 UMHC, 516 Delaware St. S.E., Minneapolis, MN 55455. Phone: 612-624-9444; FAX: 612-6264027; E-mail: rosen001@ maroon.tc.umn.edu.

Received for publication 5 July 1995 and accepted in revised form 5 September 1995.

J. Clin. Invest.

(C) The American Society for Clinical Investigation, Inc.

0021-9738/95/12/2646/08 \$2.00

Volume 96, December 1995, 2646-2653 sulfated glycoprotein-2 (SGP-2), testosterone repressed prostate message-2 (TRPM-2), ${ }^{1}$ dimeric acidic glycoprotein (DAG), SP-40,40, gp80, apo J, NA1/NA2, and glycoprotein III $(3-7)$.

Clusterin is a heterodimer consisting of two $40-\mathrm{kD}$ chains joined by a unique five-disulfide bond motif ( 8 ). The protein precursor of clusterin is encoded on a single 2-kb mRNA which is transcribed from a single copy gene located on chromosome $8(8 \mathrm{p} 21)(9,10)$. A signal peptide is present on the protein precursor. Clusterin has a long $\alpha$-helix near the amino terminal, at least six $\mathrm{N}$-linked glycosylation sites, several potential heparin-binding domains, three amphipathic helix domains, and a putative dinucleotide-binding domain $(3,6,8,11-13)$.

Clusterin is found in numerous physiologic fluids and in most organs, with the highest levels in the testes, epididymis, liver, stomach, and brain $(14,15)$. Additionally, developmental regulation of clusterin expression is seen. In the kidney, for example, clusterin is expressed in the ureteric bud but not in surrounding mesenchyme $(16,17)$. As the mesenchyme is induced to form renal epithelium, clusterin is expressed and continues to be present in developing tubules. In the developing lung, clusterin is present in the bronchial tree and its expression follows a similar time course seen with branching morphogenesis (17). No clusterin is seen in the mature lung. This temporal expression of clusterin during ontogeny at sites where critical cell interactions occur implies a role in organogenesis.

A unique and defining feature of clusterin is its induction in many organs, particularly the brain and kidney, at times of tissue injury. Despite its immediate and often prominent recruitment after injury, the role of clusterin remains elusive. Proposed functions for clusterin in this setting include apoptotic initiation, complement defense, lipid recycling, and membrane protection $(3,4,7)$.

We hypothesize that a function of clusterin in renal injury is to promote cell-cell and cell-substratum interactions. This hypothesis derives from the potent ability of clusterin to promote interactions in nonrenal cells and the typical disturbances in cell interactions that accompany renal injury. To begin to test this hypothesis, we examined the effects of clusterin on renal epithelial cell interactions. Since cell interactions are dependent on integrity of the cytoskeleton, and disruption of the cytoskeleton is an early feature of renal injury, we also examined the in vitro effects of cytoskeletal disruption on clusterin expression. Finally, we inhibited cell-substratum interactions to determine if the state of these interactions affects clusterin expression.

1. Abbreviation used in this paper: TRPM-2, testosterone repressed prostate message-2. 

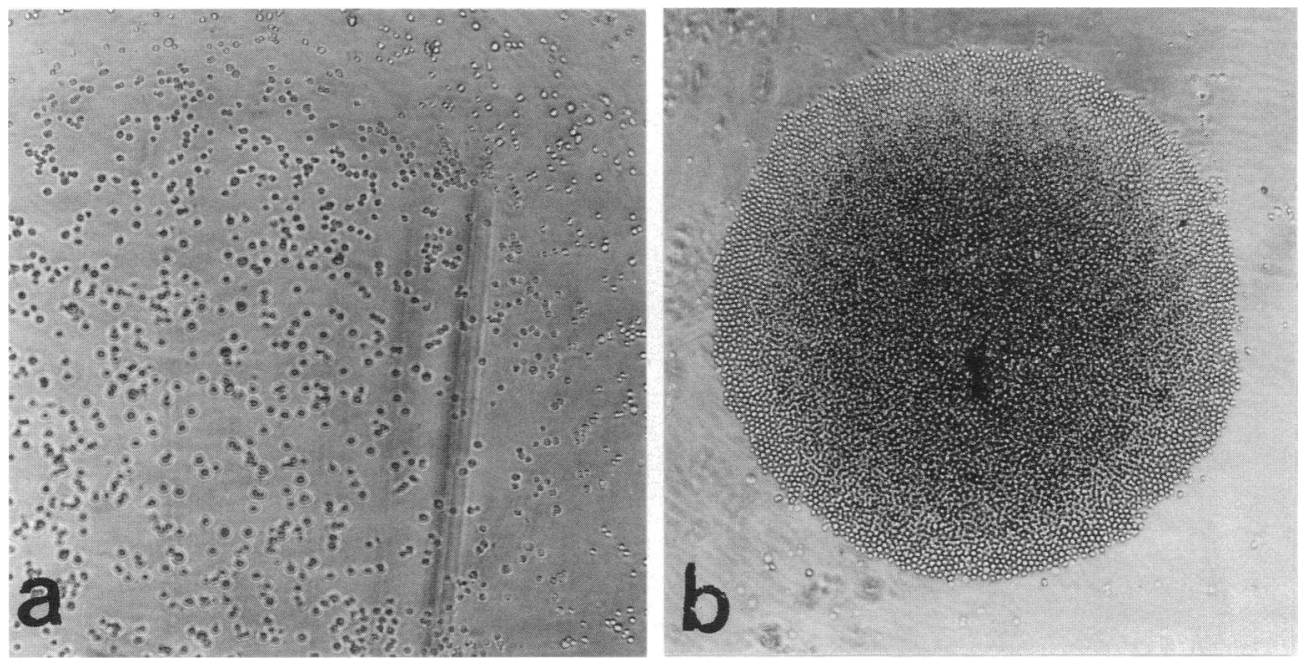

Figure 1. Cell aggregation. A single cell suspension of LLC-PK1 was incubated for $1 \mathrm{~h}$ under $(a)$ control conditions or $(b)$ with clusterin $50 \mu \mathrm{g} / \mathrm{ml}$. No aggregation was seen in the absence of clusterin ( score $=0$ ). Clusterin caused marked aggregation of cells $($ score $=4+)$.

\section{Methods}

Purification of clusterin. Clusterin was purified from fresh human sera by immunoaffinity chromatography using the mouse anti-human clusterin mAb G7 (gift of Brendan Murphy, Melbourne, Australia) (18). To each $25 \mathrm{ml}$ of sera was added $65 \mu \mathrm{l}$ of $0.2 \mathrm{M}$ phenylmethylsulfonyl fluoride (Sigma Chemical Co., St. Louis, MO) in 30\% ethanol and 3 grams of polyethylene glycol, $12 \% \mathrm{wt} / \mathrm{vol}$ (Sigma). After centrifugation, 5.75 grams polyethylene glycol, $23 \% \mathrm{wt} / \mathrm{vol}$, was added to the supernatant and the resulting precipitate was dissolved in $10 \mathrm{mM}$ EDTA, $0.5 \mathrm{mM}$ phenylmethylsulfonyl fluoride, filtered, and applied to the immunoaffinity column. The column was sequentially washed with: $(a)$ $20 \mathrm{ml}$ of $10 \mathrm{mM}$ phosphate, $500 \mathrm{mM}$ sodium chloride, $10 \mathrm{mM}$ EDTA, pH 7.4; (b) 20 ml PBS (Sigma) containing 0.5\% Triton X-100 (Research Organics, Cleveland, $\mathrm{OH}$ ) to remove apo A-1 and lipids coupled to circulating clusterin; and (c) $30 \mathrm{ml}$ PBS. Clusterin was then eluted with $0.2 \mathrm{M}$ glycine-hydrochloride, $0.5 \mathrm{M}$ sodium chloride $(\mathrm{pH} 2.8)$ and immediately neutralized with $1 \mathrm{ml}$ of $2 \mathrm{M}$ Tris- $\mathrm{HCl}$ ( $\mathrm{pH} \mathrm{7.0)}$ ). Further purification was performed by running the eluate through a protein $\mathrm{A}$ column (Sigma) to remove any contaminating immunoglobulin. The resulting sample was concentrated and purity documented by SDSPAGE performed according to the method of Laemmli (19). As expected, clusterin appeared as a $40-\mathrm{kD}$ doublet under reduced conditions and an $80-\mathrm{kD}$ band under unreduced conditions (data not shown). The concentration of clusterin was measured by the Coomassie blue dye method of Bradford using BSA (fraction V powder; Sigma) as a standard (20).

Cell culture. Porcine renal epithelial cells (LLC-PK1) were obtained from the American Type Culture Collection (Rockville, MD) at passage number 196. Cells were grown in DME (Sigma) at $37^{\circ} \mathrm{C}$ in $95 \%$ air and $5 \%$ carbon dioxide. The medium was supplemented with 5\% FBS, L-glutamine $(330 \mu \mathrm{g} / \mathrm{ml})$, Hepes $(5.9 \mathrm{mg} / \mathrm{ml})$, penicillin $(100 \mathrm{U} / \mathrm{ml})$, and streptomycin $(100 \mu \mathrm{g} / \mathrm{ml})$. All experiments were performed in basal medium Eagle's (Sigma) or PBS over a range of no more than 10 passages. Additional experiments used SK-OV-3 cells (ATCC HTB 77), an ovarian adenocarcinoma cell line grown in McCoy's $5 \mathrm{~A}$ medium (Sigma), and L-929 cells (ATCC CCL 1), a mouse fibroblast cell line grown in Dulbecco's modified Eagle's medium nutrient mixture F-12 Ham (1:1 mixture; Sigma).

Aggregation assay. A single cell suspension was prepared by treatment with $0.25 \%$ trypsin in HBSS with 0.2 grams/liter EDTA (Hyclone Laboratories, Logan, UT) followed by soybean trypsin inhibitor ( $1 \mathrm{mg} /$ $\mathrm{ml}$; Sigma). The following components were then added to each well of a 96 U-shaped well polyprostyrene microtiter plate (Costar Corp., Cambridge, MA): $65 \mu \mathrm{l}$ PBS, $10 \mu$ l clusterin (concentration variable), and $25 \mu \mathrm{l}$ cell suspension $\left(1 \times 10^{4}\right.$ cells $)$ to a total volume of $100 \mu \mathrm{l}$.
The microtiter plate was mounted in a holder at an angle of $45^{\circ}$ and rotated at $2 \mathrm{rpm}$ in a humidified incubator at $37^{\circ} \mathrm{C}$. After various incubation times, the cells were examined under a dissecting microscope (at a magnification of 40 ) and the degree of aggregation quantified by the method of Fritz and Burdzy (21). No aggregation was scored as " 0 " and a tightly packed aggregate of cells was scored as " $4+$ ". The continuum between these values was denoted " $1+$ ", " $2+$ ", or " $3+$ ".

To determine the requirements for calcium and magnesium, additional aggregation studies were performed in calcium- and magnesiumfree HBSS (Life Technologies, Grand Island, NY) containing $2.5 \mathrm{mM}$ EDTA (Sigma). To determine whether active protein synthesis was required for clusterin-induced cell aggregation, LLC-PK1 cells were incubated with $1-100 \mu \mathrm{g} / \mathrm{ml}$ cycloheximide (Sigma) for $30 \mathrm{~min}$ before and during the cell aggregation studies.

Adhesion assay. Each well of a 24-well polystyrene plate (Costar Corp.) was coated with $200 \mu \mathrm{l}$ of one of the following at $50 \mu \mathrm{g} / \mathrm{ml}$ : BSA, human fibronectin (Collaborative Biomedical Products, Bedford, MA), or human clusterin. PBS and BSA were used as negative controls, and the fibronectin as a positive control. The plate was incubated overnight in a $37^{\circ} \mathrm{C}$ humidified incubator. The wells were then washed with PBS followed by incubation with $2 \mathrm{mg} / \mathrm{ml}$ BSA in PBS to block nonspecific binding sites. A cell suspension was prepared as described above, using serum-free basal medium Eagle's containing $1 \mathrm{mg} / \mathrm{ml} \mathrm{BSA}$ instead of PBS. The flask of cells was radiolabeled the day before with $125 \mu \mathrm{l}^{51} \mathrm{Cr}$ (250-500 mCi/mg Cr; Amersham Corp., Arlington Heights, IL). The concentration of the cells was adjusted to $5-8 \times 10^{4}$ cells/ $\mathrm{ml}$ and a total of $500 \mu \mathrm{l}$ of radiolabeled cell suspension was then added to each well. The plates were incubated at $37^{\circ} \mathrm{C}$ for 30,60 , or $90 \mathrm{~min}$. Nonadherent cells were removed from each well and the individual wells were washed twice with PBS. Adherent cells were then solubilized by incubation with $1 \mathrm{M}$ sodium hydroxide for $10 \mathrm{~min}$. The washings (nonadherent cells) and solubilized (adherent) cells were counted separately in a gamma counter (Gamma 7000; Beckman Instruments Inc., Palo Alto, CA) and percent cell adhesion was calculated as adherent cells $/($ adherent cells + nonadherent cells $) \times 100$.

A dose-response curve for clusterin-induced cell adhesion was performed using clusterin concentrations ranging from 1 to $100 \mu \mathrm{g} / \mathrm{ml}$. The values for an albumin control were subtracted from the clusterin values to obtain the final percent cell adhesion. Additional adhesion assays were performed in the presence of $300 \mu \mathrm{g} / \mathrm{ml}$ of the anticlusterin $\mathrm{mAb}$ G7 or purified mouse IgG-1 Kappa (Organon Teknika Corp., Durham, NC). These antibodies were mixed with the cell suspension before placement in the well.

Spreading of the adherent cells was evaluated by performing adhesion assays as described above. The cells were then fixed with $2 \%$ glutaraldehyde (Sigma), stained with hematoxylin (Zymed Labora- 

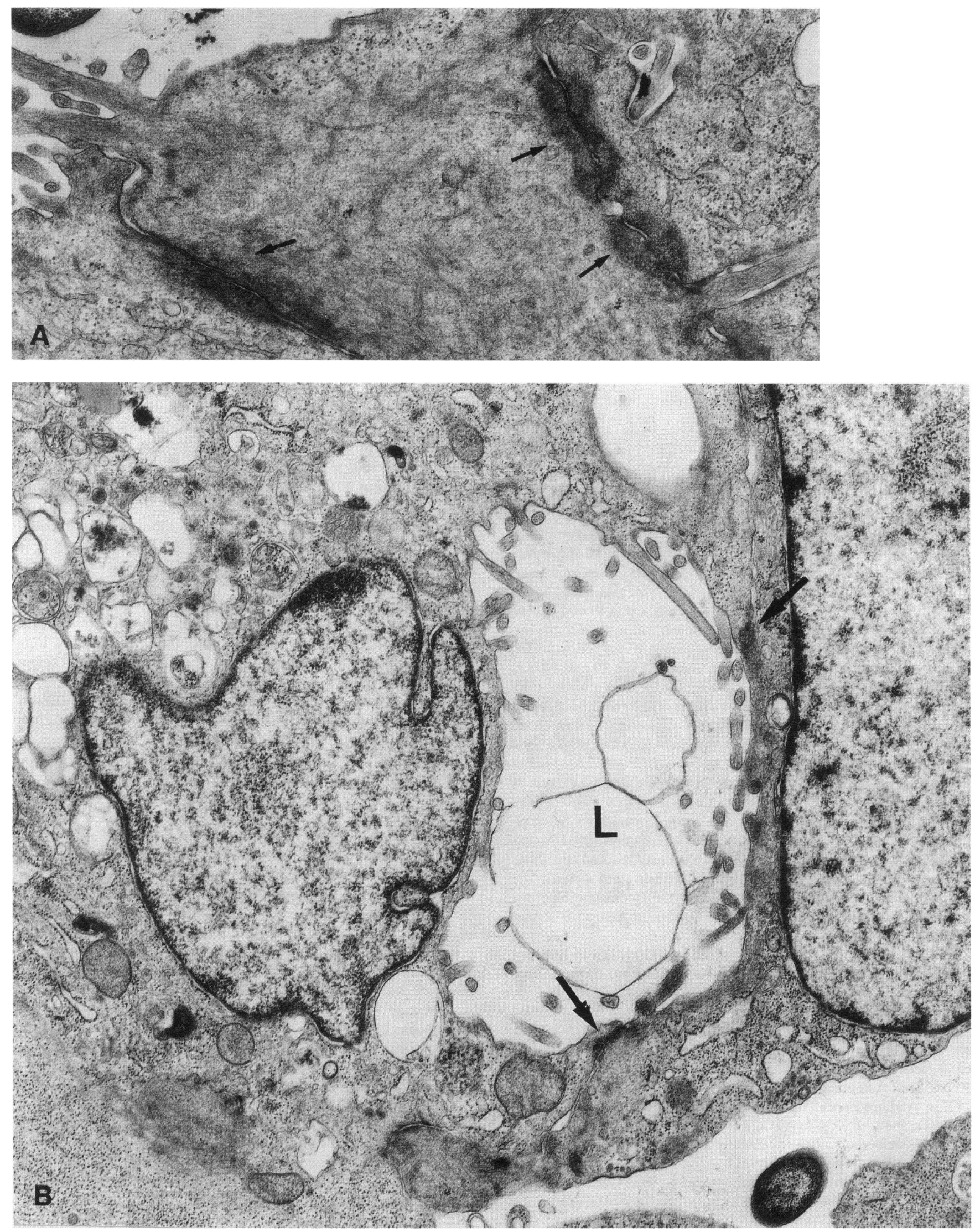

Figure 2. Electron micrograph of cell aggregate. Electron micrographs of the cell aggregates $18 \mathrm{~h}$ after addition of clusterin demonstrated $(A)$ extensive desmosome formation (arrows) and $(B)$ intercellular lumen formation $(L)$. The lumen with projecting microvilli is made up of at least two different cells as evidenced by the presence of cell junctions (arrows). 


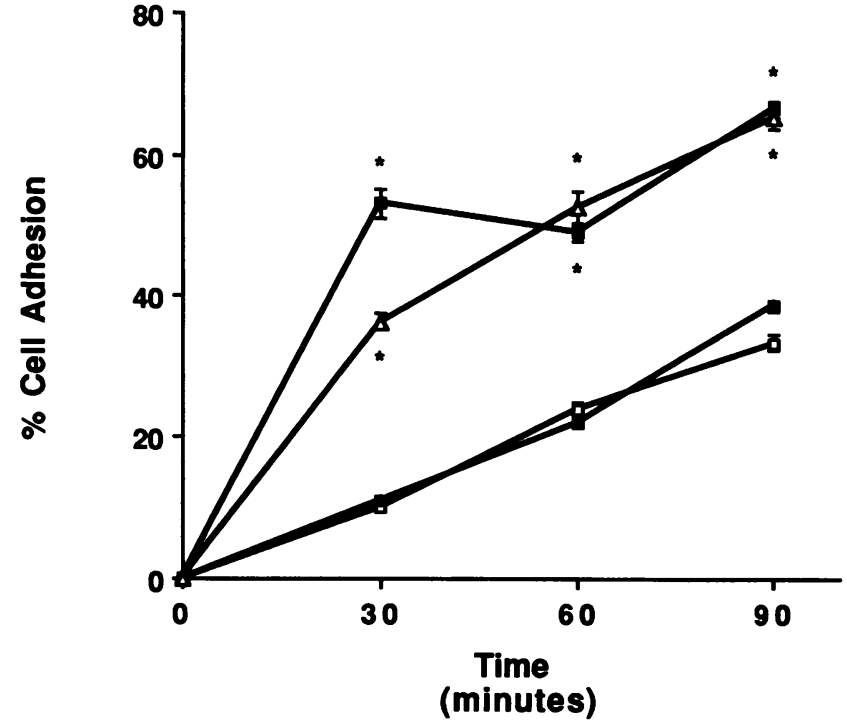

Figure 3. Time course for cell adhesion. The time course for clusterininduced cell adhesion is shown in this figure and is compared with the adhesion molecule fibronectin and to two different controls (albumin and PBS). The concentration of the proteins used to coat the wells was $50 \mu \mathrm{g} / \mathrm{ml}$. As can be seen, a similar enhancement of cell adhesion was seen for clusterin and fibronectin compared with PBS or albumin. $n$ $=6$ at each time point. ${ }^{*} P<0.05$ versus PBS or albumin. Open boxes, PBS; hatched boxes, albumin; filled boxes, clusterin; open triangles, fibronectin.

tories, Inc., South San Francisco, CA), and photographed with an Olympus BX40 inverted microscope (Tokyo, Japan) equipped with an Olympus OM-4T camera.

Electron microscopy. To determine whether clusterin promotes more permanent cell interactions, a single cell suspension of LLC-PK1 cells was incubated for $18 \mathrm{~h}$ with $50 \mu \mathrm{g} / \mathrm{ml}$ clusterin, resulting in the forma-

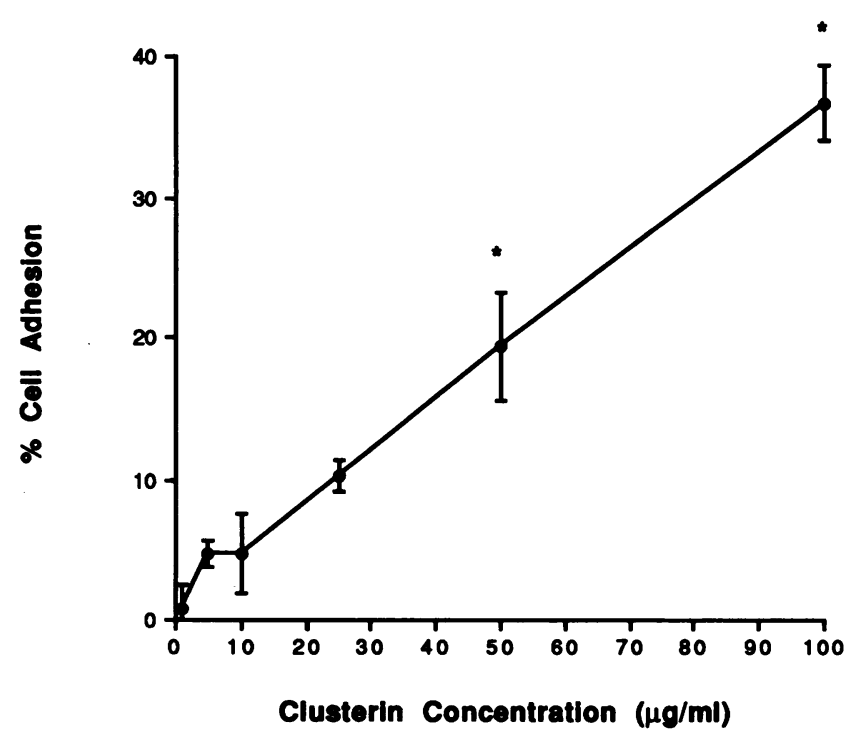

Figure 4. Dose-response of cell adhesion. The dose-response for clusterin-induced cell adhesion is shown in this figure. The values for an albumin control were subtracted from the clusterin values to obtain the final percent cell adhesion. $n=4$ at each dose. $* P<0.05$ versus all other groups.

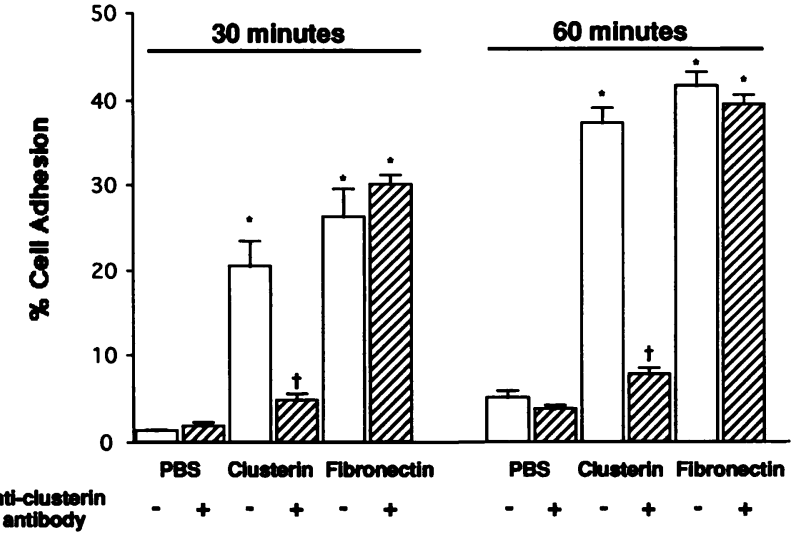

Figure 5. Effect of an anticlusterin antibody on cell adhesion. Cell adhesion was increased in the clusterin- and fibronectin-coated plates at both 30 and $60 \mathrm{~min}$. Addition of an anticlusterin antibody to the cells just before adding them to the coated wells blocked cell adhesion only in the clusterin-coated wells, demonstrating the specificity of the clusterin-induced cell adhesion. $n=6$ for each condition. ${ }^{*} P<0.05$ versus PBS. ${ }^{\dagger} P<0.05$ versus no antibody.

tion of a large aggregate of cells. The cell aggregate was centrifuged and fixed in $2.5 \%$ glutaraldehyde in Millonig's buffer, decanted, postfixed in $1.5 \%$ buffered osmium tetroxide solution for $1 \mathrm{~h}$, and decanted again. It was then progressively dehydrated in alcohol, infiltrated in sieved acetone and Polybed 812 resin (Polysciences Inc., Warrington, PA), and embedded in Polybed 812 resin. After overnight incubation in a $37^{\circ} \mathrm{C}$ oven, the cell aggregate was transferred to a $60^{\circ} \mathrm{C}$ oven and incubated for $24 \mathrm{~h}$. Thick sections were stained with toluidine blue and evaluated by light microscopy. Thin sections were stained with uranyl acetate and lead citrate and examined with a Phillips 201 transmission electron microscope (Philips Electronics, Schaumburg, IL).

Effect of cytoskeletal disruption on clusterin mRNA. Confluent cultures of LLC-PK1 cells were incubated for 5 or $24 \mathrm{~h}$ with $75 \mu \mathrm{M}$ podophyllotoxin, $50 \mu \mathrm{M}$ colchicine, or $0.2 \mu \mathrm{M}$ vinblastine (Sigma), all of which disrupt microtubules, or for $24 \mathrm{~h}$ with $39 \mu \mathrm{M}$ cytochalasin B (Sigma), which causes actin filament depolymerization. Detached and attached cells were then harvested and clusterin mRNA was quantified by Northern hybridization (see below). Disruption of microtubules was verified by immunohistochemistry using a mouse anti-chicken $\alpha$-tubulin antibody (Sigma).

Effect of cell-substratum interactions on clusterin mRNA. Because cell-substratum interactions are often perturbed during renal injury, we examined the in vitro effect of altering these interactions on clusterin expression. To inhibit cell contact to the substratum, LLC-PK1 cells were cultured on plates precoated with $1 \%$ agarose. The response of these cells was compared with cells cultured on uncoated culture plates (Becton Dickinson, Lincoln Park, NJ). The cells were harvested $48 \mathrm{~h}$ later and clusterin mRNA was quantified by Northern hybridization.

RNA extraction and Northern blot hybridization. RNA was extracted from cells subjected to the conditions described above by the method of Chomczynski and Sacchi (22). Clusterin mRNA was quantitated by Northern hybridization as described previously (23). The cDNA probe was rat TRPM-2 (clusterin; gift of Martin Tenniswood, University of Ottawa, Ottawa, Ontario, Canada) (24). For preparation of the cDNA probe, we used the method of random oligomer-primer labeling (Stratagene La Jolla, CA $)$ with $\left[{ }^{32} \mathrm{P}\right] \mathrm{dCTP}(6,000 \mathrm{Ci} / \mathrm{mmol}$; NEN DuPont, Wilmington, DE). The specific activity of the probe was $1-2 \times 10^{9}$ $\mathrm{cpm} / \mu \mathrm{g}$ DNA.

Statistical analysis. Statistical significance was defined as $P<0.05$ and the results were presented as mean \pm SEM. The significance of the differences was analyzed by the Student's $t$ test of unpaired data by ANOVA, followed by the Bonferroni test for multiple group comparisons. 


\section{Results}

Cell aggregation. Clusterin induced marked renal epithelial cell aggregation. In the absence of clusterin, cells remained in a single cell suspension (Fig. $1 a$ ), whereas in the presence of $50 \mu \mathrm{g} / \mathrm{ml}$ clusterin, a tight aggregate of cells was seen when examined at $60 \mathrm{~min}$ (Fig. $1 \mathrm{~b}$ ). Cell aggregation was seen at concentrations as low as $2.5 \mu \mathrm{g} / \mathrm{ml}$ and the degree of aggregation increased with increasing clusterin concentrations, plateauing at $50 \mu \mathrm{g} / \mathrm{ml}$. Cells began to aggregate as early as 5 min after the addition of $50 \mu \mathrm{g} / \mathrm{ml}$ clusterin, with maximal aggregation seen at $45 \mathrm{~min}$. Electron micrographs of the cell aggregates $18 \mathrm{~h}$ after the addition of clusterin demonstrated extensive desmosome formation (Fig. $2 A$ ). In many cases, intercellular lumen formation occurred (Fig. $2 B$ ). Thus, clusterin not only caused cells to aggregate but it also facilitated more permanent cell interactions.

There was no effect on the degree of cell aggregation when the assay was performed in the absence of either calcium or both calcium and magnesium. Pretreatment of cells with cycloheximide at a dose which inhibits protein synthesis did not affect clusterin-induced cell aggregation, providing evidence that prior protein synthesis is not necessary.

In contrast to LLC-PK1 cells, no aggregation was seen with L-929 cells and only minimal aggregation was seen with SKOV-3 cells after clusterin addition under similar experimental conditions (data not shown).

Cell adhesion. Cell adhesion was significantly increased by clusterin in a time- and dose-dependent manner (Figs. 3 and 4 ). The time course of clusterin-induced cell adhesion was similar to that of fibronectin (Fig. 3). An anticlusterin mAb G7 was used to test for the specificity of the clusterin-induced cell adhesion. The mAb inhibited cell adhesion to clusterin but not to albumin or fibronectin (Fig. 5). The control antibody had no effect on clusterin-induced cell adhesion. In addition to promoting cell adhesion, clusterin also enhanced cell spreading (Fig. 6). These studies provide evidence that clusterin is a potent cell adhesion and spreading molecule.

As with aggregation, however, the adhesive properties of clusterin were not seen with all cell types evaluated. SK-OV-3 cells exhibited marked adhesion with fibronectin and laminin, though no increase above control with clusterin. Similarly, clusterin did not enhance adhesion of L-929 cells (data not shown).

Effect of cytoskeleton disruption on clusterin $m R N A$. Treatment with $75 \mu \mathrm{M}$ podophyllotoxin resulted in disruption of microtubules as documented by immunochemistry using an antitubulin antibody (data not shown). Additionally, rounding up and detachment of some cells was seen. Induction of clusterin mRNA was seen in the podophyllotoxin-treated cells at both 5 and $24 \mathrm{~h}$ compared with the low levels seen in control cells (Fig. 7). In data not shown, treatment with two other microtubular disrupting agents, $50 \mu \mathrm{M}$ colchicine and $0.2 \mu \mathrm{M}$ vinblastine, resulted in a similar increase in clusterin mRNA. Disruption of microfilaments by treatment with $39 \mu \mathrm{M}$ cytochalasin B for $24 \mathrm{~h}$ also increased clusterin mRNA compared with control cells (Fig. 8). Thus, disruption of both microtubules and microfilaments was associated with an increase in clusterin mRNA.

Effect of cell-substratum interactions on clusterin mRNA. Cells cultured on uncoated plates formed a typical monolayer and had low basal levels of clusterin. When cell-substratum interactions were inhibited by culturing cells on plates coated
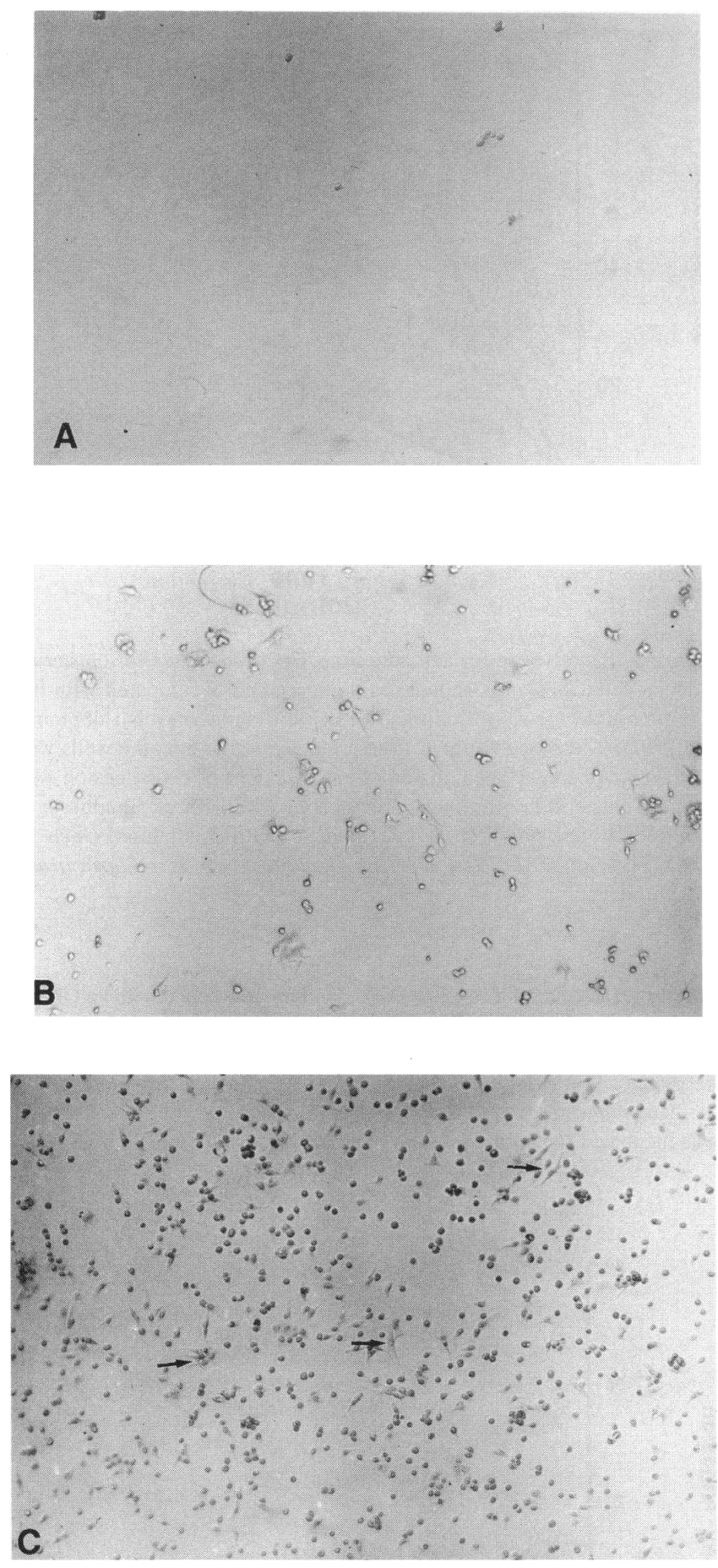

Figure 6. Cell spreading. Phase contrast photographs $6 \mathrm{~h}$ after adding an equivalent number of LLC-PK1 cells added to $(A)$ control (PBS) coated wells, $(B)$ albumin $(50 \mu \mathrm{g} / \mathrm{ml})$ coated wells, and $(C)$ clusterin ( $50 \mu \mathrm{g} / \mathrm{ml}$ ) coated wells. The number of adherent cells was greater in the clusterin-coated wells as was the degree of cell spreading (arrows).

with agarose, an increase in clusterin mRNA was observed (Fig. 9).

\section{Discussion}

The major findings of this paper are that clusterin is a renal epithelial cell aggregation and adhesion molecule, and that 


\section{5 hour incubation}
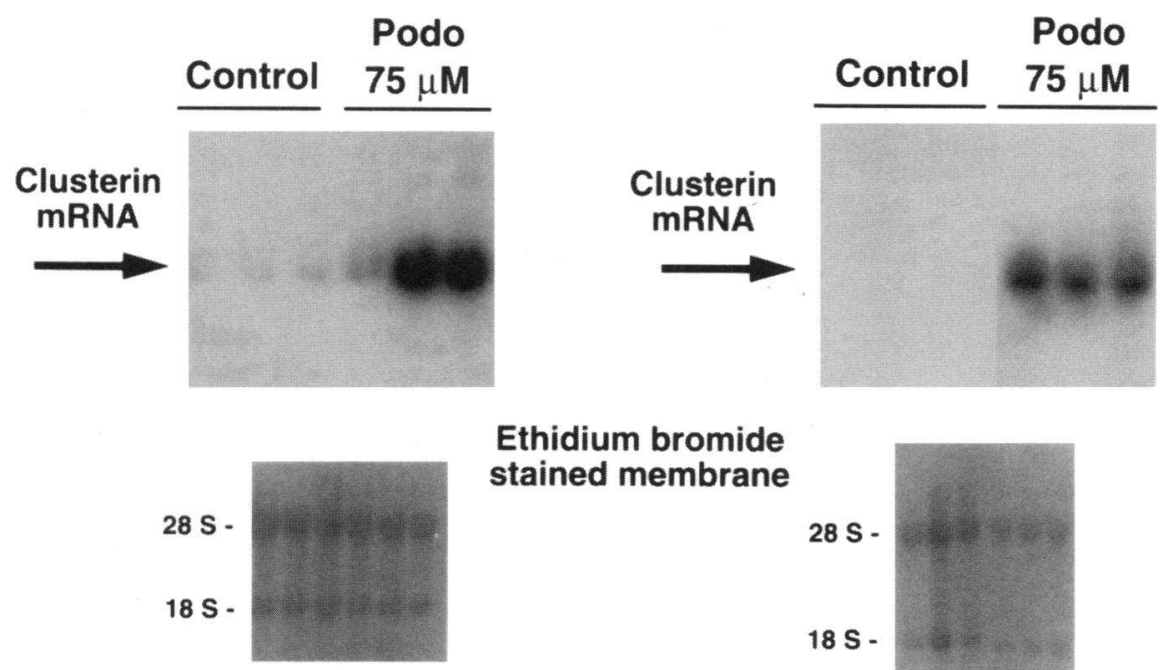

\section{Ethidium bromide} stained membrane

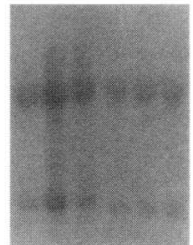

Figure 7. Microtubular disruption. LLC-PK1 cells were incubated with the microtubule disrupting agent podophyllotoxin (Podo; 75 $\mu \mathrm{M}$ ) for 5 or $24 \mathrm{~h}$. Each lane of the Northern blots contains $20 \mu \mathrm{g}$ of total LLC-PK1 RNA from a separate plate of cells. The ethidium bromide-stained membranes serve as controls for loading and transfer. Compared with the low levels of clusterin mRNA seen in control cells, treatment with $75 \mu \mathrm{M}$ podophyllotoxin for $5 \mathrm{~h}$ resulted in an increase of clusterin mRNA. Clusterin mRNA was also increased after $24 \mathrm{~h}$ of podophyllotoxin treatment as seen in the right hand Northern blot. changes in clusterin expression are responsive to changes in the cytoskeleton and to the state of cell-substratum interactions.

The ability of clusterin to promote renal epithelial cell aggregation is consistent with its effect on other cell types. Clusterin has been shown to aggregate erythrocytes, spermatozoa, mouse testes TM- 4 cells, and primary cultures of rat Sertoli cells (1, 2 ). In this study, aggregation of LLC-PK1 cells began at $5 \mathrm{~min}$, reached a maximum by $45 \mathrm{~min}$, and was dose dependent. The degree of aggregation was not dependent on the presence of extracellular calcium or magnesium and did not require new protein synthesis by the cells. The mechanism for this cell aggregation is unknown, though the failure of clusterin to aggre- gate all cell types argues against a nonspecific phenomenon. A unique clusterin receptor has not been identified, although glycoprotein 330 ( $\mathrm{gp} \mathrm{330}$ ), a receptor involved in the endocytosis of a number of ligands, can specifically bind clusterin and mediate its uptake into cells (25). Furthermore, the active site/ $\mathrm{s}$ of the clusterin molecule responsible for cell aggregation is/ are not known.

Increased cell aggregation occurs when interactions between substratum and anchorage-dependent cells are the weakest (26). Given the increase in clusterin mRNA observed when LLCPK1 cells were cultured on agarose, it is conceivable that clusterin plays a role in the aggregation. Taken further, cells which
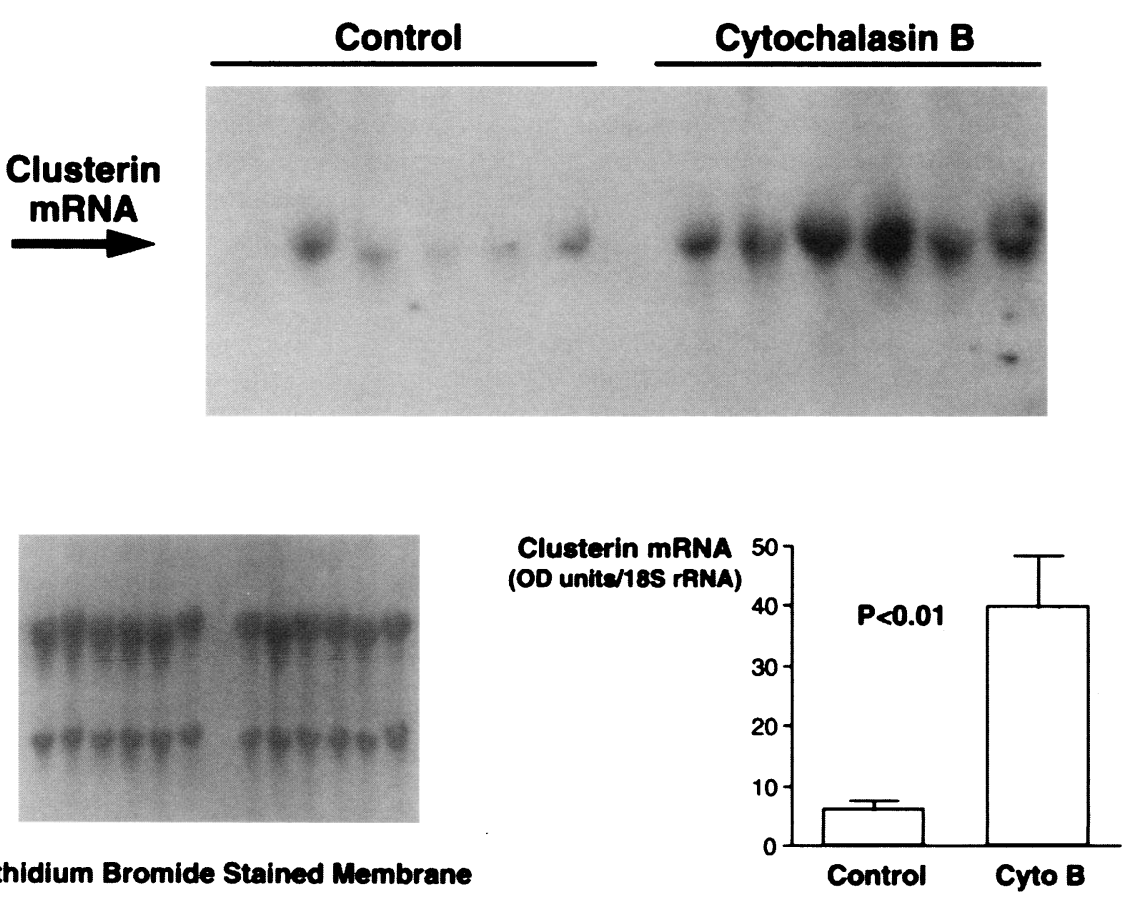

Figure 8. Microfilament disruption. LLCPK1 cells were incubated for $24 \mathrm{~h}$ with the microfilament-disrupting agent cytochalasin B $(39 \mu \mathrm{M})$. Each lane of the Northern blot contains $20 \mu \mathrm{g}$ of total LLC-PK1 RNA from a separate plate of cells. The ethidium bromide-stained membranes serve as controls for loading and transfer. A graph of the corrected optical density values is displayed. Compared with the low levels of clusterin mRNA seen in control cells, treatment with cytochalasin $B$ resulted in an increase of clusterin mRNA ( $126 \pm 12$ vs. $28 \pm 3$ OD units; $P<0.01 ; n=5$ both groups). 

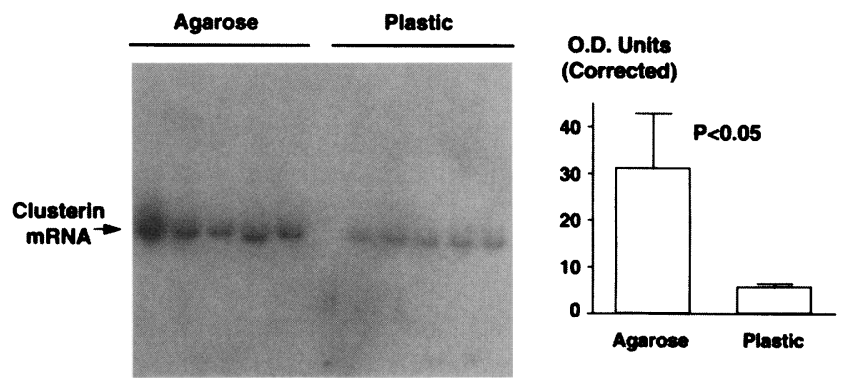

Figure 9. Inhibition of cell-substratum interactions. LLC-PK1 cells were cultured for $48 \mathrm{~h}$ on agarose-coated plates to inhibit cell attachment or uncoated plates (plastic) which promoted cell attachment. Each lane represents a different plate of cells and contains $20 \mu \mathrm{g}$ of total LLCPK1 RNA. A graphic display of the results corrected for differences in RNA loading is shown on the right. An increase in clusterin mRNA was observed when cell-substratum interactions were inhibited by culturing the cells on the agarose-coated plates (agarose: $30.9 \pm 11.7 \mathrm{vs.}$ plastic: $5.5 \pm 0.9$ OD units; $P<0.05 ; n=5$ both groups).

lose their cell-substratum contacts might induce clusterin to maintain cell-cell proximity or, perhaps, to reestablish contact with the substratum.

In addition to causing renal epithelial cell aggregation, clusterin is a cell adhesion molecule with potency equivalent to the prototypic adhesion molecule fibronectin. We have defined the time course and dose-response for this adhesion. The inhibition of cell adhesion by an anticlusterin antibody demonstrates the specificity of this effect. Clusterin is not a member of any known class of adhesion molecules, and the structure provides few clues as to the mechanism of the cell adhesion. For example, there are no arginine-glycine-aspartic acid (RGD) or YIGSR sequences. However, clusterin can bind heparin and fibrin, suggesting a role for clusterin in the interaction between clusterin, cells, and extracellular matrix $(27,28)$. In fact, Matrigel (Collaborative Biomedical Products), a commercially available basement membrane gel, contains biologically active clusterin $(20-35 \mu \mathrm{g} / \mathrm{ml})$ which may contribute some of the effects of this gel on cellular morphology and behavior (29).

Clusterin may also be involved in more complex cell interactions. When vascular smooth muscle cells are grown in culture they generate morphologically differentiated nodules composed of nonproliferating cells embedded in matrix. Clusterin mRNA and protein are increased in these nodules in a time course which suggests a role in the nodule formation $(29,30)$. Addition of anticlusterin antibody inhibits nodule formation (29). Another example is the expression of clusterin during ontogeny at sites where critical cell interactions occur, such as the branching bronchial tree and the ureteric bud before mesenchymal condensation $(16,17)$.

Increased expression of clusterin is seen in a wide array of disease states, pointing to a role in the tissue response to injury. These states include diseases of the central nervous system, kidney, and heart, as well as atherosclerosis and cancer $(5,7$, 31-38). Proposed functions for clusterin in the setting of tissue injury include apoptotic initiation, complement defense, lipid recycling, membrane protection, and maintenance of cell-cell or cell-substratum contacts $(3,4,7)$. Definitive evidence for any of these proposed functions is scant, and the possibility exists that more than one, or an as yet undefined function, may be relevant.
We propose that clusterin is induced at times of tissue injury to promote cell-cell and cell-substratum interactions which are perturbed in these settings. This hypothesis is supported by both the ability of clusterin to promote cell interactions and the typical disturbances in cell interactions that accompany states associated with clusterin induction. This hypothesis is particularly pertinent to renal injury. Abnormalities in cell interactions that follow renal injury lead to cell rounding, retraction, and detachment; decreased binding of cells to matrix components; and aberrant cell-cell attachments (39-45).

The cytoskeleton plays a key role in the maintenance of intercellular junctions and the attachment of cells to their substratum. Disruption of the cytoskeleton is an early finding in renal injury, leading to alterations in numerous cellular functions including the loss of cell contacts $(39-41,43)$. The observed increase in clusterin mRNA after disruption of microtubules or microfilaments provides a link between changes in the cytoskeleton, renal injury, and clusterin induction.

Even mild injury can lead to profound nephron dysfunction mediated in part through alterations in cell attachment, a finding which is supported by the presence of viable epithelial cells in the urine after acute renal failure (46). Detachment of tubular epithelial cells from the substratum leads to denuded epithelium and a consequent back leak of filtrate. Induction of clusterin under these conditions, with its subsequent enhancement of cell interactions, could be a beneficial response. Maintenance of cell-cell contacts by clusterin may be important in exchange of critical nutrients or other factors between cells, perhaps across gap junctions, and maintenance of cell-substratum contacts could prevent or lessen cell sloughing. In addition, maintenance of cell proximity would allow the normal junctional contacts to become reestablished once the injury passes. Many clinical conditions characterized by alterations in cell attachment, namely renal cystic disease and apoptosis, are associated with clusterin induction, further supporting our hypothesis (16, $36,47-49$ ).

In conclusion, clusterin induces renal epithelial cell aggregation and adhesion. Disruption of the cytoskeleton and loss of cell-substratum interactions, both early changes after renal injury, lead to induction of clusterin mRNA. These findings, combined with the induction of clusterin in a wide variety of injuries or states of abnormal cell attachment, suggest that clusterin functions to maintain cell interactions in settings such as renal injury where normal interactions are perturbed.

\section{Acknowledgments}

We thank Martin Tenniswood for the TRPM-2 (clusterin) cDNA, Brendan Murphy for the mouse anti-human clusterin monoclonal antibody, Michael Griswold for the polyclonal rabbit anti-rat clusterin antiserum, and Mildred Priddy for editorial assistance.

This work was supported by US Public Health Service grants R29DK43075 (M. E. Rosenberg), CA60658 (A. P. N. Skubitz), and a National Research Service Award (J. R. Silkensen); an American Heart Association Minnesota Affiliate Grant-in-Aid (K. M. Skubitz); the Baxter Extramural Grant Program; and a grant from the Minnesota Medical Foundation. Jeffrey Dvergsten was supported by an American Heart Association Medical Student Research Fellowship.

\section{References}

1. Blaschuk, O., K. Burdzy, and I. B. Fritz. 1983. Purification and characterization of a cell-aggregating factor (clusterin), the major glycoprotein in ram rete testis fluid. J. Biol. Chem. 12:7714-7720. 
2. Fritz, I. B., K. Burdzy, B. Sétchell, and O. Blaschuk. 1983. Ram rete testes fluid contains a protein (clusterin) which influences cell-cell interactions in vitro. Biol. Reprod. 28:1173-1188.

3. Jenne, D. E., and J. Tschopp. 1992. Clusterin: the intriguing guises of a widely expressed glycoprotein. TIBS (Trends Biochem. Sci.). 17:154-159.

4. Fritz, I. B., and B. Murphy. 1993. Clusterin. Insights into a multifunctional protein. Trends Endocrinol. Metab. 4:41-45.

5. Michel, D., J.-G. Chabot, E. Moyse, M. Danik, and R. Quirion. 1992 Possible functions of a new genetic marker in central nervous system: the sulfated glycoprotein-2 (SGP-2). Synapse (NY). 11:105-111.

6. Jordan-Starck, T. C., D. P. Witte, B. J. Aronow, and J. A. K. Harmony 1992. Apolipoprotein J: a membrane policeman? Curr. Opin. Lipidol. 3:75-85.

7. Rosenberg, M. E., J. Dvergsten, and R. Correa-Rotter. 1993. Clusterin: an enigmatic protein recruited by diverse stimuli. J. Lab. Clin. Med. 121:205-214.

8. Kirszbaum, L., S. E. Bozas, and I. D. Walker. 1992. SP-40, 40, a protein involved in the control of the complement pathway, possesses a unique array of disulphide bridges. FEBS Lett. 297:70-76.

9. Tobe, T., S. Minoshima, S. Yamase, N.-H. Choi, M. Tomita, and N. Shimizu. 1991. Assignment of a human serum glycoprotein SP-40, 40 gene (CLI) to chromosome 8. Cytogenet. Cell Genet. 57:193-195.

10. Purrello, M., S. Bettuzzi, C. Di Pietro, E. Mirabile, M. Di Blasi, R. Rimini, K.-H. Grzeschik, C. Ingletti, A. Corti, and G. Sichel. 1991. The gene for SP-40, 40, human homolog of rat sulfated glycoprotein 2 , rat clusterin, and rat testosteronerepressed prostate message 2, maps to chromosome 8. Genomics. 10:151-156.

11. Kirszbaum, L., J. A. Sharpe, B. Murphy, A. J. F. d'Apice, B. Classon, P. Hudson, and I. D. Walker. 1989. Molecular cloning and characterization of the novel, human complement-associated protein, SP-40, 40: a link between the complement and reproductive systems. EMBO (Eur. Mol. Biol. Organ.) J. 8:711718.

12. Jenne, D. E., and J. Tschopp. 1989. Molecular structure and functiona characterization of a human complement cytolysis inhibitor found in blood and seminal plasma: identity to sulfated glycoprotein 2 , a constituent of rat testis fluid. Proc. Natl. Acad. Sci. USA. 86:7123-7127.

13. Tsuruta, J. K., K. Wong, I. B. Fritz, and M. D. Griswold. 1990. Structura analysis of sulphated glycoprotein 2 from amino acid sequence. Relationship to clusterin and serum protein 40, 40. Biochem. J. 268:571-578.

14. Jordan-Starck, T. C., S. D. Lund, D. P. Witte, B. J. Aronow, C. A. Ley, W. D. Stuart, D. K. Swertfeger, L. R. Clayton, S. F. Sells, B. Paigen, and J. A K. Harmony. 1994. Mouse apolipoprotein J: characterization of a gene implicated in atherosclerosis. J. Lipid Res. 35:194-210.

15. Aronow, B. J., D. S. Lund, T. L. Brown, J. A. K. Harmony, and D. P Witte. 1993. Apolipoprotein J expression at fluid-tissue interfaces: potential role in barrier cytoprotection. Proc. Natl. Acad. Sci. USA. 90:725-729.

16. Harding, M. A., L. J. Chadwick, V. H. Gattone II, and J. P. Calvet. 1991 The SGP-2 gene is developmentally regulated in the mouse kidney and abnormally expressed in collecting duct cysts in polycystic kidney disease. Dev. Biol. 146:483-490.

17. French, L. E., A. Chonn, D. Ducrest, B. Baumann, D. Belin, A. Wohlwend J. Z. Kiss, A.-P. Sappino, J. Tschopp, and J. A. Schifferli. 1993. Murine clusterin molecular cloning and mRNA localization of a gene associated with epithelia differentiation processes during embryogenesis. J. Cell Biol. 122:1119-1130.

18. Murphy, B. F., L. Kirszbaum, I. D. Walker, and A. J. F. d'Apice. 1988 SP-40,40 a newly identified normal human serum protein found in the SC5b-9 complex of complement and in the immune deposits in glomerulonephritis. $J$. Clin. Invest. 81:1858-1864.

19. Laemmli, U. K. 1970. Cleavage of structural proteins during the assembly of the head of bacteriophage $T_{4}$. Nature (Lond.). 227:680-685.

20. Bradford, M. M. 1976. A rapid and sensitive method for the quantitation of microgram quantities of protein utilizing the principle of protein dye binding. Anal. Biochem. 72:248-254.

21. Fritz, I. B., and K. Burdzy. 1989. Novel action of carnitine: inhibition of aggregation of dispersed cells elicited by clusterin in vitro. J. Cell. Physiol. 140:18-28.

22. Chomczynski, P., and N. Sacchi. 1987. Single-step method of RNA isolation by acid guanidinium thiocyanate-phenol-chloroform extraction. Anal. Biochem. 162:156-157.

23. Correa-Rotter, R., C. N. Mariash, and M. E. Rosenberg. 1992. Loading and transfer control for Northern hybridization. Biotechniques. 12:154-158.

24. Wong, P., J. Pineault, J. Lakins, D. Taillefer, J. Léger, C. Wang, and M. Tenniswood. 1993. Genomic organization and expression of the rat TRPM-2 (clusterin) gene, a gene implicated in apoptosis. J. Biol. Chem. 268:5021-5031.
25. Kounnas, M. Z., E. B. Loukinova, S. Stefansson, J. A. K. Harmony, B. H. Brewer, D. K Strickland, and W. S Argraves 1995. Identification of glycoprotein 330 as a receptor for apolipoprotein J/clusterin. J. Biol. Chem. 270:13070-13075.

26. Tung, P. S., K. Burdzy, K. Wong, and I. B. Fritz. 1992. Competition between cell-substratum interactions and cell-cell interactions. J. Cell. Physiol. 152:410-421.

27. Millis, A. J. T., M. Hoyle, and L. Kent. 1986. In vitro expression of a 38,000 dalton heparin-binding glycoprotein by morphologically differentiated smooth muscle cells. J. Cell. Physiol. 127:366-372.

28. Han, J. R., M. Suiko, C. C. Liu, and M. C. Liu. 1991. Post-translational modifications and binding properties of the apically secreted $80-\mathrm{kDa}$ glycoprotein from Madin-Darby canine kidney cells: similarities to the C-terminal portion of the basolaterally secreted fibronectin. Arch Biochem. Biophys. 286:337-345.

29. Thomas-Salgar, S., and J. T. Millis. 1994. Clusterin expression in differentiating smooth muscle cells. J. Biol. Chem. 269:17879-17885.

30. Diemer, V., M. Hoyle, C. Baglioni, and A. J. T. Millis. 1992. Expression of porcine complement cytolysis inhibitor mRNA in cultured aortic smooth muscle cells. Changes during differentiation in vitro. J. Biol. Chem. 267:5257-5264.

31. May, P. C., and C. E. Finch. 1992. Sulfated glycoprotein 2: new relationships of this multifunctional protein to neurodegeneration. TINS (Trends Neurosci.). 15:391-396.

32. Rosenberg, M. E., and J. Silkensen. 1995. Clusterin and the kidney. Exp. Nephrol. 3:9-14.

33. Correa-Rotter, R., T. H. Hostetter, J. C. Manivel, A. A. Eddy, and M. E. Rosenberg. 1992. Intrarenal distribution of clusterin following reduction of renal mass. Kidney Int. 41:938-950.

34. Murphy, B. F., D. J. Davies, W. Morrow, and A. J. F. d'Apice. 1989 Localization of terminal complement components, S-protein and SP-40, 40 in renal biopsies. Pathology. 21:275-278.

35. French, L. E., J. Tschopp, and J. A. Schifferli. 1992. Clusterin in renal tissue: preferential localization with the terminal complement complex and immunoglobulin deposits in glomeruli. Clin. Exp. Immunol. 88:389-393.

36. Dvergsten, J., J. C. Manivel, R. Correa-Rotter, and M. E. Rosenberg. 1994. Expression of clusterin in human renal diseases. Kidney Int. 45:828-835.

37. Witte, D. P., B. J. Aronow, M. L. Stauderman, W. D. Stuart, M. A. Clay, R. A. Gruppo, S. H. Jenkins, and J. A. K. Harmony. 1993. Platelet activation releases megakaryocyte-synthesized apolipoprotein $\mathrm{J}$, a highly abundant protein in atheromatous lesions. Am. J. Pathol. 143:763-773.

38. Väkevä, A., P. Laurila, and S. Meri. 1993. Co-deposition of clusterin with the complement membrane attack complex in myocardial infarction. Immunology. 80:177-182.

39. You, Y.-D., D. J. Hirsch, and N. S. Morgunov. 1992. Functional integrity of proximal tubule cells. Effects of hypoxia and ischemia. J. Am. Soc. Nephrol. 3.965-974.

40. Bacallao, R., and L. G. Fine. 1989. Molecular events in the organization of renal tubular epithelium: from nephrogenesis to regeneration. Am. J. Physiol. 257:F913-F924.

41. Weinberg, J. M. 1991. The cell biology of ischemic renal injury. Kidney Int. 39:476-500.

42. Molitoris, B. A., and W. J. Nelson. 1990. Alterations in the establishment and maintenance of epithelial cell polarity as a basis for disease processes. $J$. Clin. Invest. 85:3-9.

43. Molitoris, B. 1991. New insights into the cell biology of ischemic acute renal failure. J. Am. Soc. Nephrol. 1:1263-1270.

44. Bonventre, J. V. 1993. Mechanisms of ischemic acute renal failure. Kidney Int. 43:1160-1178.

45. Goligorsky, M. S., W. Lieberthal, L. Racusen, and E. E. Simon. 1993. Integrin receptors in renal tubular epithelium: new insights into pathophysiology of acute renal failure. Am. J. Physiol. 264 (Renal Fluid Electrolyte Physiol. 33):F1-F8.

46. Racusen, L. C., B. A. Fivush, Y.-L. Li, and K. Solez 1991. Dissociation of tubular cell detachment and tubular cell death in clinical and experimental "acute tubular necrosis". Lab Invest. 64:546-556.

47. Calvet, J. P. 1993. Polycystic kidney disease: primary extracellular matrix abnormality of defective cellular differentiation? Kidney Int. 43:101-108.

48. Rocco, M. V., E. G. Neilson, J. R. Hoyer, and F. N. Ziyadeh. 1992 Attenuated expression of epithelial cell adhesion molecules in murine polycystic kidney disease. Am. J. Physiol. 262:F679-F686.

49. Rosenberg M. E. J. C Manivel, F. A. Carone, and Y. S Kanwar 1995. Genesis of renal cysts is associated with clusterin expression in experimental cystic disease. J. Am. Soc. Nephrol. 5:1669-1674. 